\title{
Therapeutic mechanisms of granulocyte-colony stimulating factor in methotrexate-induced parotid lesion in adult rats and possible role of telocytes: A histological study
}

\section{Original Article}

\author{
Abeer I. Omar, Marwa M. Yousry and Eman A. Farag \\ Department of Histology, Faculty of Medicine, Cairo University, Cairo, Egypt
}

\begin{abstract}
Background: Worldwide, Methotrexate (MTX) is used to treat neoplastic and non-neoplastic diseases despite its severe side-effects. One of these adverse effects is salivary dysfunction that can aggravate MTX mucotoxic effects. Such effects interfere with the patients' quality of life and increase morbidities and mortalities. Available treatments for salivary dysfunction have many drawbacks. Mobilization of bone marrow haematopoietic stem cells (BMHSCs) by human Granulocyte-Colony Stimulating Factor (G-CSF) used in many diseases showed promising results.

Aim of the work: To detect the therapeutic effect of G-CSF on MTX-induced parotid lesion highlighting its possible mechanisms and the role of telocytes.

Materials and Methods: Forty-one albino rats were divided into 3 groups; control, MTX and Neupogen-treated groups. All animals were weighed and sacrificed after 6 days. Parotid homogenates of 6 rats from each group were used to measure total protein concentration, amylase activity and malondialdehyde (MDA) value. The right parotids of the remaining animals of each group were processed to Paraffin blocks while, the left ones were processed to resin blocks. Paraffin sections stained with Hematoxylin and Eosin and immunohistochemical stains for CD34 and platelet-derived growth factor receptor-alpha (PDGFR- $\alpha$ ) as well as resin semithin and ultrathin sections were examined. Body weight, biochemical results, number of immune-positive cells, difference between numbers of CD34+ and PDGFR- $\alpha+$ cells (stem cells number), acini and ducts numbers and diameters were statistically analysed.

Results: MTX group revealed diarrhoea, decreased body weight in addition to, degenerated acinar and ductal cells, and telocytes. However, Neupogen-treated group demonstrated almost normal histological features. Immunohistochemically, the treated group showed significant increase in CD34+ cells, PDGFR- $\alpha+$ cells and stem cells number versus MTX group.

Conclusions: G-CSF had a therapeutic effect on MTX-induced parotid degeneration through its direct effects, BMHSCs mobilization and telocytes preservation.
\end{abstract}

Key Words: MTX; G-CSF; Parotid; Telocytes; CD34; PDGFR- $\alpha$

Revised: 29 October 2017, Accepted: 5 November 2017

Corresponding Author: Abeer I. Omar, Tel.:+201002596677, E-mail: Kaboree2002@gmail.com

ISSN: 1110-0559, Vol.41, No.1

\section{INTRODUCTION}

Surgical removal of the tumour was the only available treatment for cancer patients during the last century. It was combined with increased morbidities and mortalities. Recently, use of chemotherapy led to better survival rates $^{[1]}$. Thus, it has been widely used for curing different neoplasms either alone or accompanying surgery and/or radiotherapy ${ }^{[2]}$ despite its cytotoxicity to normal as well as cancer tissues $^{[3]}$.

Methotrexate (MTX) is a folic acid antagonist chemotherapeutic agent. Its efficacy, like other chemotherapeutic agents, is often restricted by its severe side-effects ${ }^{[1]}$. Folate or folinic acid supplements could reduce its side-effects and therapeutic effects, as well[ ${ }^{[4]}$.
Mucositis is one of the commonest chemotherapeutic side-effects occurred as early as 24-48 h. It has been reported to upsurge patients' weight loss, morbidities, hospital stay, cost of treatment and mortalities. Moreover, oral mucositis causes oropharyngeal pain, dental caries, oral infections and bacteraemia besides taste, swallowing and phonation problems ${ }^{[5]}$. Thus, it does not only affect patient's nutrition and quality of life during and after treatment ${ }^{[6]}$ but also delays treatment completion and dose reduction ${ }^{[7]}$.

Saliva secreted by salivary glands acini and modulated by duct cells has a vital role in maintaining oral tissue integrity. It provides lubrication, digestion, enamel preservation and antibacterial, antifungal and antiinflammatory functions by its different components ${ }^{[7,8]}$. 
The major salivary glands secrete $90 \%$ of the daily saliva where $25 \%$ is produced by parotid gland ${ }^{[9]}$.

Salivary glands malfunction changes the composition and/or decreases the amount of saliva leading to dry mouth (xerostomia) ${ }^{[10]}$ manifested clinically by oral mucositis ${ }^{[11]}$. Such malfunction was proven to occur with chemotherapy and aggravate its secondary mucotoxic effects ${ }^{[12]}$. Drugs used for salivary gland stimulation in xerostomia have many adverse effects like excessive sweating, tremors, nervousness and diarrhoea ${ }^{[13]}$. So, an urgent need for another effective treatment is essential.

Human Granulocyte-Colony Stimulating Factor (G-CSF), a haematopoietic cytokine, was reported to be able to mobilize bone marrow haematopoietic stem cells (BMHSCs) $^{[14]}$. Thus, it is considered as a non-invasive, convenient and less costly way for regenerative medicine ${ }^{[15]}$.

Telocytes are unique interstitial cells present in the stroma of many organs ${ }^{[16]}$ as heart, skeletal muscles, lungs, gastrointestinal tract, salivary glands, urinary system, meninges, uterus and skin ${ }^{[17]}$. They have very long prolongations named telopodes that form 3D network. Such virtual network allows telocytes to communicate with themselves, other parenchymatous cells, nerve endings and blood vessels ${ }^{[18]}$.

This study aimed to detect the histological and biochemical changes occurred in parotid gland secondary to MTX, a chemotherapy model, and the potential therapeutic effect of G-CSF on these changes in adult albino rats pointing out its possible mechanisms and telocytes role.

\section{MATERIALS AND METHODS}

\section{I) Animals}

Forty-one adult male albino rats (200-220 g) were treated according to Cairo University Animal Use Committee guidelines. They were housed at the animal house, Faculty of Medicine, bred in wire mesh cages at $241 \pm{ }^{\circ} \mathrm{C}$ and normal light/dark cycle and provided with ordinary rat chow with free water and food access.

\section{II) Materials}

Methotrexate (MTX): It was purchased from Hospira Company (Maidenhead, UK) as vials for injection, each contains $50 \mathrm{mg}$ MTX.

Neupogen: It was purchased from F. Hoffmann-La Roche Ltd, Basel. Kirin-Amgen Inc., Switzerland in the form of $0.5 \mathrm{ml}$ pre-filled syringe, each contains $300 \mu \mathrm{g}$ Filgrastim (recombinant-methionyl human G-CSF).

Anti-CD34 antibody: rabbit polyclonal antibody, ab185732, abcam, Cambridge, UK.
Anti-Platelet-derived growth factor receptor-alpha (PDGFR- $\alpha$ ) antibody: mouse monoclonal antibody, C-9: sc-398206, Santa Cruz Biotechnology, Inc., Heidelberg, Germany.

\section{III) Experimental design}

The rats were divided into three groups and incidence of diarrhoea was observed.

Group I (control group, 15 rats): The animals were subdivided into three subgroups ( 5 rats each):

Subgroup IA: received no treatment.

Subgroup IB: received single intraperitoneal (IP) injection of $1 \mathrm{ml}$ saline.

Subgroup IC: prepared as subgroup IB and 24h later the rats were given subcutaneous (SC) injection of $0.5 \mathrm{ml}$ of $5 \%$ glucose/day for 5 days.

Group II (MTX group, 13 rats): Each rat received single IP injection of $40 \mathrm{mg} / \mathrm{kg}$ MTX freshly dissolved in $1 \mathrm{ml}$ saline ${ }^{[19]}$ at day one of the experiment.

Group III (Neupogen-treated group, 13 rats): Each animal was prepared as in group II then it received SC injection of Neupogen as $50 \mu \mathrm{g} / \mathrm{kg} /$ day freshly dissolved in $0.5 \mathrm{ml}$ of $5 \%$ glucose for 5 days $^{[15]}$. Neupogen was given $24 \mathrm{~h}$ after MTX administration as recommended by the manufacturing company i.e. at the second experimental day.

\section{IV) Experimental procedure}

After 6 days all animals were weighed then sacrificed after anaesthetized with intraperitoneal ketamine $(90 \mathrm{mg} /$ $\mathrm{kg}) / x y l a z i n e(15 \mathrm{mg} / \mathrm{kg})^{[20]}$. The two parotids of each animal were dissected and weighed.

1. Biochemical investigations: Parotid homogenates of the two parotids of two rats from each control subgroup and those of six rats from each other group were prepared ${ }^{[21]}$. Total protein concentration ${ }^{[22]}$, amylase activity ${ }^{[23]}$ and value of malondialdehyde (MDA, a lipid peroxidation indicator $)^{[24]}$ were measured at Biochemistry Department, Faculty of Medicine, Cairo University.

2 Histological studies: The right parotids of the remaining animals of each group were fixed in $10 \%$ formol saline, kept for $24 \mathrm{~h}$ then processed to paraffin blocks. Six micrometers-thick sections were cut and stained with:

a) Hematoxylin and Eosin $(\mathrm{H} \& \mathrm{E})^{[25]}$.

b) Immunohistochemical staining ${ }^{[26]}$ for:

CD34: BMHSCs, telocytes and endothelial cells marker.

PDGFR- $\alpha$ : marker for telocytes. 
Sections for immunohistochemical stains were boiled for $10 \mathrm{~min}$ in $10 \mathrm{mM}$ citrate buffer (AP9003) at $\mathrm{pH} 6$ for antigen retrieval then incubated for $1 \mathrm{~h}$ with the primary antibodies. Ultravision detection system (TP-015-HD) was used to complete immunostaining and Mayer's hematoxylin (TA-060-MH) was used for counterstaining. Citrate buffer, Ultravision detection system and Mayer's hematoxylin were purchased from Labvision Thermo Scientific, Fremont, California, USA.

c) Electron microscopic study:

The left parotids were cut into small fragments $(0.5$ $1.0 \mathrm{~mm}^{3}$ ), prefixed in $2.5 \%$ glutaraldehyde for $2 \mathrm{~h}$ then postfixed in $1 \%$ osmium tetroxide in $0.1 \mathrm{M}$ phosphate buffer at $\mathrm{pH} 7.4$ and $4{ }^{\circ} \mathrm{C}$ for $2 \mathrm{~h}$. Dehydration and resin embedding were done to obtain resin blocks ${ }^{[27]}$. Semithin $(1 \mu \mathrm{m})$ and ultrathin $(60-90 \mathrm{~nm})$ sections were cut using a Leica ultracut (UCT) (Glienicker, Berlin, Germany) at Electron Microscope Research Unit, Faculty of Agriculture. Semithin sections were stained with toluidine blue (1\%) and examined by light microscope while, ultrathin ones were stained with uranyl acetate then lead citrate and examined by transmission electron microscope [TEM] (JEOL JEM-1400, Japan) $)^{[28]}$.

Telocytes and their telopodes were digitally coloured blue, using Adobe Photoshop CC 2014, for their better visualization.

d) Morphometric studies:

Ten non-overlapping fields from different sections of each group were used to measure:

Mean number of CD34+ cells (excluding endothelial cells) (x400).

Mean number of PDGFR- $\alpha+$ cells (x400).

Mean difference between numbers of CD34+ and PDGFR- $\alpha+$ cells (BMHSCs mean number) (x400).

Mean number of acini and ducts in H\&E stained sections (x100).

Mean diameter of acini and ducts in H\&E stained sections (x100).

This was done using Leica Qwin-500 LTD-software image analysis computer system (Cambridge, England) at Histology Department, Faculty of Medicine, Cairo University.

e) Statistical analysis:

The morphometric and the biochemical measurements were statistically analysed using "IBM SPSS statistics 21 " and the data were reported as mean \pm standard deviation (SD). One-way analysis of variance (ANOVA) followed by "Tuckey" post-hoc test were used to determine the statistical significance $(\mathrm{P}<0.05$ was considered significant $)$ [29].

\section{RESULTS}

\section{General observations}

No deaths were noticed in all rats during the experiment. However, there were diarrhoea and significantly decreased body weight in MTX group (Table 1).

All control subgroups showed similar biochemical and histological results so, they were collectively named control group.

\section{Biochemical results and statistical analysis}

MTX group revealed a significant increase in MDA level and a significant decrease in unstimulated parotid weight, total protein and amylase activity versus groups I and III (Table 1).

\section{1) Histological results:}

\section{Control group (group I):}

H\&E stained sections showed normal parotid gland histological structure. It appeared formed of lobes and lobules separated by delicate connective tissue (CT) septa. The parotid parenchyma consisted of closely packed purely serous acini and duct system comprised of intralobular (intercalated and striated) and excretory ducts. The striated ducts (SDs) were the most prominent intralobular ducts while the intercalated ducts (IDs) were hardly recognized being compressed in-between the acini (Figs. 1a \& 1b).

In semithin sections, the acini were surrounded by a clear basement membrane and their cells showed apical uniform dense secretory granules also detected in IDs. Moreover, SDs revealed basal striations and occasional dark cell extending from the basement membrane to the lumen. There were blood vessels within CT septa and myoepithelial cells enclosed between their basal laminae and those of the intralobular ducts (Fig. 1c).

Immunohistochemically stained sections demonstrated some CD34+ cells including endothelial cells, stem cells and telocytes with their characteristic prolongations (Fig. 1d), besides, the positive immunoreaction for PDGFR- $\alpha$ in telocytes and their telopodes (Fig. 1e).

Ultrastructurally, the serous acini appeared rounded 
with narrow lumina and lined by pyramidal cells. These cells have basal regular oval nuclei with peripheral heterochromatin and prominent nucleoli, basal closely packed parallel cisternae of rough endoplasmic reticulum (rER), scattered mitochondria of different shapes and sizes and apical uniform homogenous electron-dense granules. Their lateral borders showed interdigitations and junctional complex around the lumen. Blood vessels and nerve trunks were also demonstrated in $\mathrm{CT}$.

The intercalated ducts were lined with cubical cells with central rounded nuclei and prominent nucleoli, little organelles and few apical electron-dense granules. They have lateral interdigitations with junctional complex around the lumen and apical few microvilli. Myoepithelial cells, intraepithelial lymphocytes and dendritic cells with their characteristic nuclear indentation were noticed. Furthermore, SDs were lined with high cuboidal cells with central rounded euchromatic nuclei. Their lateral borders were almost straight; however, the basal borders demonstrated complex infoldings enclosing rod-shaped mitochondria and the apical borders showed numerous microvilli. Dark cells with many processes were observed in some SDs (representing another type of duct cells or duct cells at a different functional stage).

Telocytes were seen in CT around acini and ducts as solitary triangular cells with large euchromatic nuclei and prominent nucleoli, little cytoplasm full of rER and mitochondria. They had long moniliform prolongations (telopodes) with thin fibrillar segments (podomers) and thick segments (podoms) surrounding the organelles (Figs. 1f-1j).

\section{MTX group (group II):}

Examination of H\&E stained sections revealed glandular disorganization with wide CT septa and acinar amalgamation. These septa enclosed dilated congested blood vessels, mononuclear infiltration and multiple adipocytes. The acinar and ductal cells showed shrunken darkly stained nuclei and multiple cytoplasmic vacuolations. Moreover, the intralobular ducts could not be differentiated into IDs and SDs. Furthermore, intralobular and excretory ducts demonstrated epithelial lining disruption and luminal dilatation with retained secretions (Figs. 2a \& 2b).

Semithin sections revealed irregular acinar and ductal nuclei, almost absent secretory granules and cytoplasmic vacuolations that, in some cells, joined together into large vacuoles replacing the whole cells and displacing their nuclei. The acinar basement membranes were disrupted and the blood vessels were dilated and congested. Mast cells with their specific metachromatically stained granules were observed within CT septa near the blood vessels where some of their granules appeared dispersed in these septa (Fig. 2c).

Immunohistochemically, there were many CD34 immunopositive stem cells, endothelial cells and telocytes (Fig. 2d). Additionally, there were few PDGFR- $\alpha+$ telocytes with their unique long prolongations (Fig. 2e).

Ultrathin sections of acini and IDs showed irregular nuclei with chromatin clumping, multiple vacuolations that sometimes joined together and became of variable shapes and sizes, reduced size and content of secretory granules and ruptured apical borders with cytoplasmic remnants in their lumina. Additionally, the acini revealed dilated rER, swollen mitochondria with degenerated cristae and interior vacuolations. Moreover, stagnant secretion was noticed in IDs that were surrounded by myoepithelial cells. The SDs demonstrated thinning of their epithelial lining with loss of basal infoldings and mitochondrial swelling and degeneration. Furthermore, there were cytoplasmic vacuolations and rupture of SDs' apical borders with subsequent cytoplasmic escape to the lumen that was filled with stagnant secretions. The dark cells were noticed in some SDs. Telocytes appeared with condensed irregular shrunken and/or fragmented nuclei, cytoplasmic vacuolations and reduced organelles. Dilated congested blood vessels, adipocytes, thick fibrous septa and increased collagen fibers surrounding fibroblasts were also noticed (Figs. 2f-2h).

\section{Neupogen-treated group (group III):}

Sections stained with H\&E (Figs. 3a \& 3b) and toluidine blue (Fig. 3c) and those examined by TEM (Figs. 3f \& 3g) showed apparently normal histological features except for the presence of few vacuolations, pyknotic nuclei and degenerated mitochondria, congested blood vessels in addition to multiple adjacent acinar lumina.

Immunohistochemical study showed multiple CD34+ stem cells and telocytes (Fig. 3d). In addition, there was observable increase in PDGFR- $\alpha+$ telocytes with their characteristic prolongations (Fig. 3e).

\section{Morphometric results:}

CD34+ cells were significantly increased in group II versus group I and in group III versus group II; however, PDGFR $-\alpha+$ cells revealed significant decrease in group II compared to groups I and III . Moreover, BMHSCs number showed significant increase in group II compared to group I and in group III compared to group II. In addition, MTX group revealed significant increase in acinar and ductal diameters and significant decrease in their numbers versus other groups (Table 1). 
Table 1: Mean value \pm SD of body \& unstimulated parotid weight, biochemical \& morphometric parameters in all groups

\begin{tabular}{|c|c|c|c|}
\hline Parameters & Group I & Group II & Group III \\
\hline Mean body weight (g) & $226.2 \pm 11.8$ & $149.4 \pm 10.06^{\mathrm{a}}$ & $205.8 \pm 29.3^{b}$ \\
\hline Mean unstimulated parotid weight (mg) & $211.2 \pm 6.5$ & $174.4 \pm 9.35^{\mathrm{a}}$ & $202.2 \pm 9.3^{\mathrm{b}}$ \\
\hline Mean value of MDA (nmoL/mg tissue) & $2.19 \pm 0.4$ & $14.8 \pm 1.4^{\mathrm{a}}$ & $3.1 \pm 0.4^{b}$ \\
\hline Mean value of total protein ( $\mathrm{mg} / \mathrm{mg}$ tissue) & $86.9 \pm 4.11$ & $55.8 \pm 3.9^{\mathrm{a}}$ & $80.7 \pm 10.3^{b}$ \\
\hline Mean value of amylase activity ( $\mu / \mathrm{mg}$ tissue) & $217.4 \pm 4.08$ & $124.8 \pm 3.38^{\mathrm{a}}$ & $208.9 \pm 12.6^{b}$ \\
\hline Mean number of CD34+ cells & $12.6 \pm 1.17$ & $14.9 \pm 1.19^{\mathrm{a}}$ & $22.6 \pm 1.89^{\mathrm{ab}}$ \\
\hline Mean number of PDGFR- $\alpha+$ cells & $7.8 \pm 0.7$ & $5.3 \pm 1.05^{\mathrm{a}}$ & $6.9 \pm 1.19^{b}$ \\
\hline Mean difference between CD34+ \&PDGF- $\alpha$ numbers & $4.8 \pm 1.13$ & $9.6 \pm 1.4^{\mathrm{a}}$ & $15.7 \pm 1.9^{\mathrm{ab}}$ \\
\hline Mean number of acini & $86.5 \pm 6.3$ & $44.1 \pm 2.9^{\mathrm{a}}$ & $77.7 \pm 12.6^{\mathrm{b}}$ \\
\hline Mean number of intralobular ducts & $7.2 \pm 1.31$ & $4.0 \pm 0.9^{\mathrm{a}}$ & $5.8 \pm 1.4^{b}$ \\
\hline Mean diameter of acini $(\mu \mathrm{m})$ & $32.1 \pm 4.45$ & $46.9 \pm 7.4^{\mathrm{a}}$ & $37.6 \pm 4.2^{\mathrm{b}}$ \\
\hline Mean diameter of intralobular ducts $(\mu \mathrm{m})$ & $39.11 \pm 5.5$ & $55.7 \pm 7.19^{\mathrm{a}}$ & $45.4 \pm 6.3^{\mathrm{b}}$ \\
\hline
\end{tabular}

a: $\mathrm{P}<0.05$ as compared to group I.

b: $\mathrm{P}<0.05$ as compared to group II. 

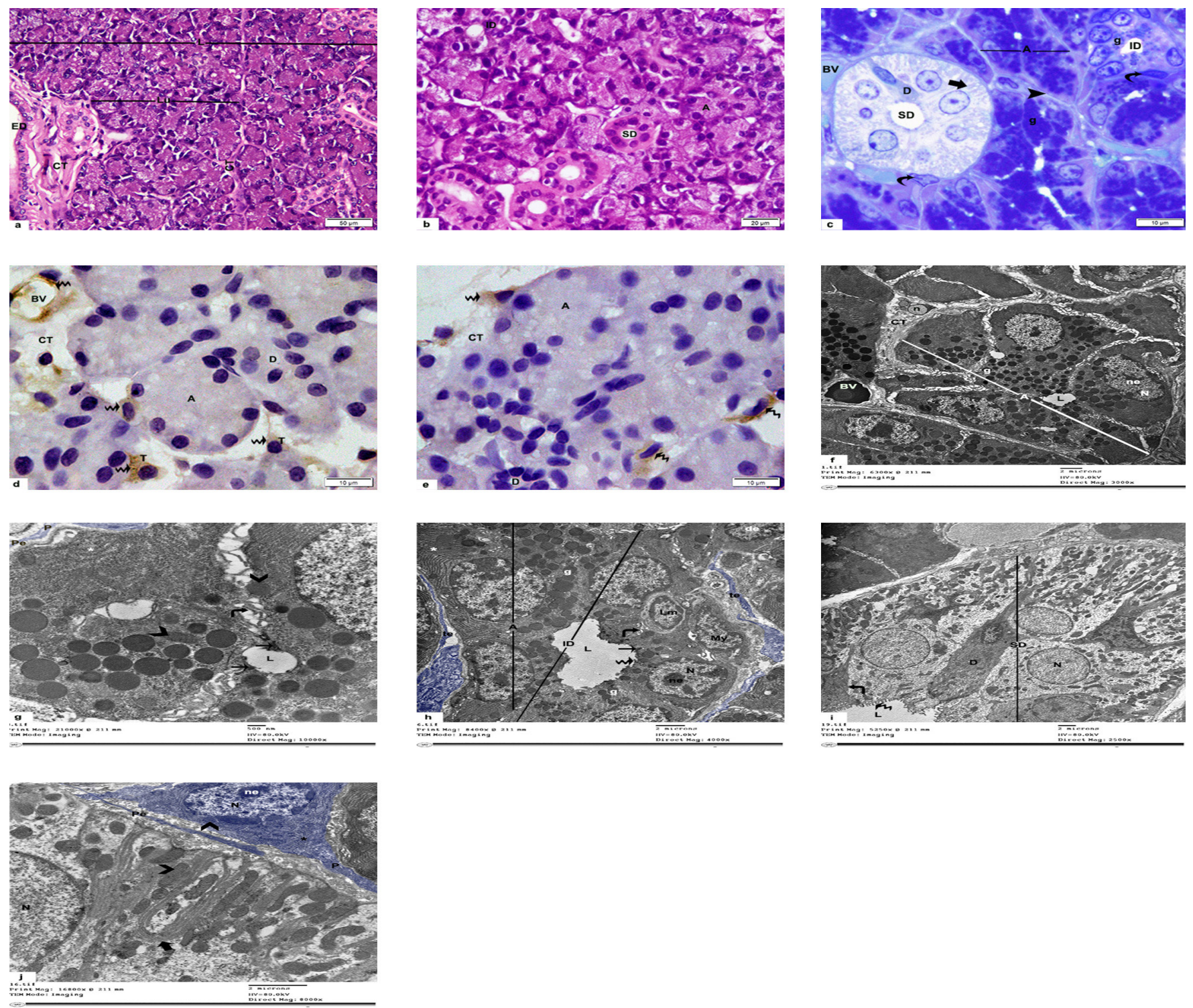

Fig. 1: Light microscopical photomicrographs of the control sections showing: a: Parotid's lobe (L) and lobules (Lu) separated by delicate connective tissue (CT) septa containing excretory ducts (ED) [H\&E, x200]. b: The lobule consists of closely packed purely serous acini (A) and intralobular duct system of intercalated (ID) and striated (SD) ducts [H\&E, x400]. c: The acini (A) appear with clear basement membranes (arrow head), and apical uniform dense secretory granules (g), that are also detected in intercalated duct (ID). Striated duct (SD) exhibits basal striations (thick arrow) and darkly stained cell (D), extending from the basement membrane to the lumen. Notice the myoepithelial cells (curved arrows) enclosed between their basal laminae and those of the intralobular ducts. Blood vessels (BV) can also be noticed [Toluidine blue, x1000]. d: Some CD34 immune-positive cells (endothelial cells, stem cells and telocytes) (wavy arrows) are detected. Some of these cells show long prolongations suggesting that they are telocytes (T). Notice the presence of acini (A), duct (D) \& blood vessel (BV) within the septa (CT) [anti CD34 immunohistochemical stain, x1000]. e: Some PDGFR- $\alpha+$ cells (wavy arrows) are present around the acini (A) \& in the septa (CT). Ducts (D) can also be seen [anti PDGFR- $\alpha$ immunohistochemical stain, x1000].

TEM photomicrographs illustrating: f: Rounded serous acini (A) with narrow lumen (L) lined by pyramidal cells having basal regular oval nuclei $(\mathrm{N})$ with peripheral heterochromatin and prominent nucleoli (ne). Note the presence of apical uniform homogenous electron-dense granules (g). CT septa (CT) with a blood vessel (BV) and a nerve trunk (n) are observed [x3000]. g: The acinar cells show basal closely packed parallel cisternae of $\mathrm{rER}(*) \&$ scattered mitochondria (arrow heads) of different shapes and sizes. Additionally there are lateral interdigitations (right-angled arrow) and junctional complex (thin arrows) around the lumen (L). Part of telocyte consisting of podomer (pe) and podom (P) (digitally colored blue) is clearly seen [x10000]. h: Transition between an acinus and ID showing acinar cells (A) with basal rER (*) \& apical secretory granules (g). The cubical cells of intercalated duct (ID) have central rounded nuclei (N) with prominent nucleoli (ne), little organelles and few apical electron-dense granules (g). Additionally, the lateral borders show interdigitations (right-angled arrow) with junctional complex (thin arrow) around the lumen (L). Few apical microvilli (wavy arrow) are also noted. Myoepithelial cell (My), intraepithelial lymphocyte (Lm), dendritic cell (de) with their characteristic nuclear indentation are noticed. Parts of telocytes \& their telopodes (te) (digitally colored blue) can be seen [x4000]. i: Striated duct (SD) is lined with high cuboidal cells with central rounded euchromatic nuclei $(\mathrm{N})$. Almost straight lateral borders (right-angled arrow) \& numerous apical microvilli (wavy arrow) projecting into the lumen (L) are demonstrated. Moreover, there are dark cells (D) with many processes within the lining of the SD [x2500]. j: The basal borders of the striated duct demonstrate complex infoldings (thick arrow) enclosing rod-shaped mitochondria (arrow head). Part of the euchromatic nucleus (N) of $\mathrm{SD}$ is noted. Part of a triangular telocyte (digitally colored blue) shows large euchromatic nucleus $(\mathrm{N})$ with prominent nucleolus (ne), little cytoplasm full of rER $(*)$ and mitochondria (arrow head) and part of its thick segment surrounding the organelles (podoms) (p). Notice the presence of a thin fibrillar segment (podomers) (pe) of another telocyte [x8000]. 

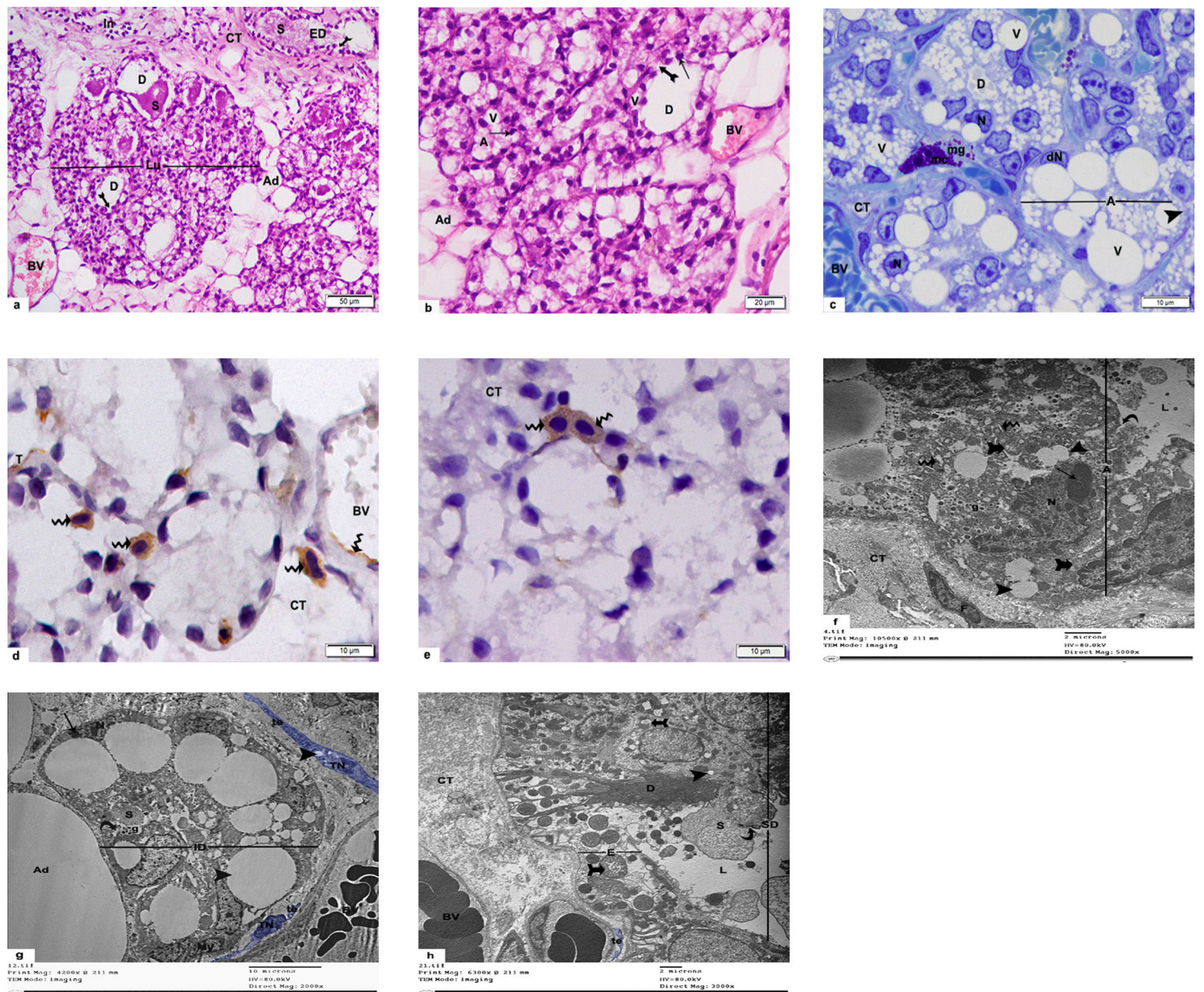

Fig. 2: Light microscopical photomicrographs of MTX group's sections showing: a: Disorganized lobules (Lu) with acinar amalgamation separated by wide CT septa (CT). These septa have dilated congested blood vessel (BV), inflammatory infiltration (In), multiple adipocytes (Ad) and excretory duct (ED). This ED shows epithelial disruption (bifid arrow) and luminal dilatation with retained secretions (S). Note that the intralobular ducts (D) are dilated, cannot be differentiated into IDs and SDs and show stagnant secretion (S) and epithelial disruption (bifid arrow) [H\&E, x200]. b: Cells lining the acini (A) and (D) show shrunken darkly stained nuclei (thin arrows), and multiple cytoplasmic vacuolations (V). Furthermore, epithelial disruption (bifid arrow) of the intralobular ducts can be demonstrated. Dilated congested blood vessel (BV) and multiple adipocytes (Ad) are also seen [H\&E, x400]. c: Acini (A) and intralobular ducts (D) exhibit irregular nuclei (N), almost absent secretory granules and presence of cytoplasmic vacuolations $(\mathrm{V})$ that in some cells, coalesce together into large vacuoles replacing the whole cells and displacing their nuclei $(\mathrm{dN})$. In addition, there are disrupted basement membrane (arrow head) \& dilated congested blood vessel (BV). Metachromatically stained mast cells' (mc) granules (mg) are observed within CT septa (CT) near the BV where some of their granules appeared dispersed in these septa [Toluidine blue, x1000]. d: Many CD34 immuno-positive cells (endothelial cells, stem cells and telocytes) (wavy arrows). Few of these cells show the characteristic telopodes of telocytes (T). Notice the presence of a blood vessel (BV) within CT septa (CT) [anti CD34 immunohistochemical stain, x1000]. e: Few PDGFR- $\alpha+$ cells (wavy arrows) with their characteristic prolongations are seen within CT septa (CT) [anti PDGFR- $\alpha$ immunohistochemical stain, x1000].

TEM photomicrographs of MTX group's sections demonstrating: $\mathrm{f}$ : An acinus (A) with ruptured apical border and cytoplasmic remnants (curved arrow) in its lumen ( L), irregular nuclei $(\mathrm{N})$ with clumped chromatin (thin arrow), multiple vacuolations (arrow heads) that sometimes fuse together and become of variable shapes and sizes. Moreover, there are dilated rER (wavy arrows) and swollen mitochondria (bifid arrows) with degenerated cristae and interior vacuolations. Notice the reduced size and contents of secretory granules (g). Thick fibrous septa (CT) with increased collagen fibers surrounding fibroblast (F) are also demonstrated [x5000]. g: The intercalated duct (ID) has rupture apical border with cytoplasmic remnants (curved arrow) in its lumen that contains stagnant secretion (S). It also reveals irregular nuclei (N) with chromatin clumps (thin arrow), multiple vacuolations (arrow head) that sometimes fuse together giving vacuoles of different shapes and sizes and diminished size and content of secretory granules (g). Additionally, degenerated telocytes with their characteristic telopodes (te) (digitally colored blue) shows cytoplasmic vacuolations (arrowhead), reduced organelles and condensed, irregular, shrunken and/or fragmented nuclei (TN). Myoepithelial cell (My) is seen around the ID. Note the existence of adipocytes (Ad) and dilated blood vessel (BV) [x2000]. h: Striated duct (SD) with epithelial thinning and basal infoldings loss (E), cytoplasmic vacuolations (arrowhead) and mitochondrial swelling and degeneration (bifid arrows) are noted. Additionally, there is ruptured apical border (curved arrow) with cytoplasmic escape to the lumen (L) that filled with stagnant secretions (S). Moreover, there is thick fibrous septa (CT) reveals dilated congested blood vessels (BV), and telopode (te) (digitally colored blue). Note the presence of dark cell (D) within the duct epithelium [x3000]. 

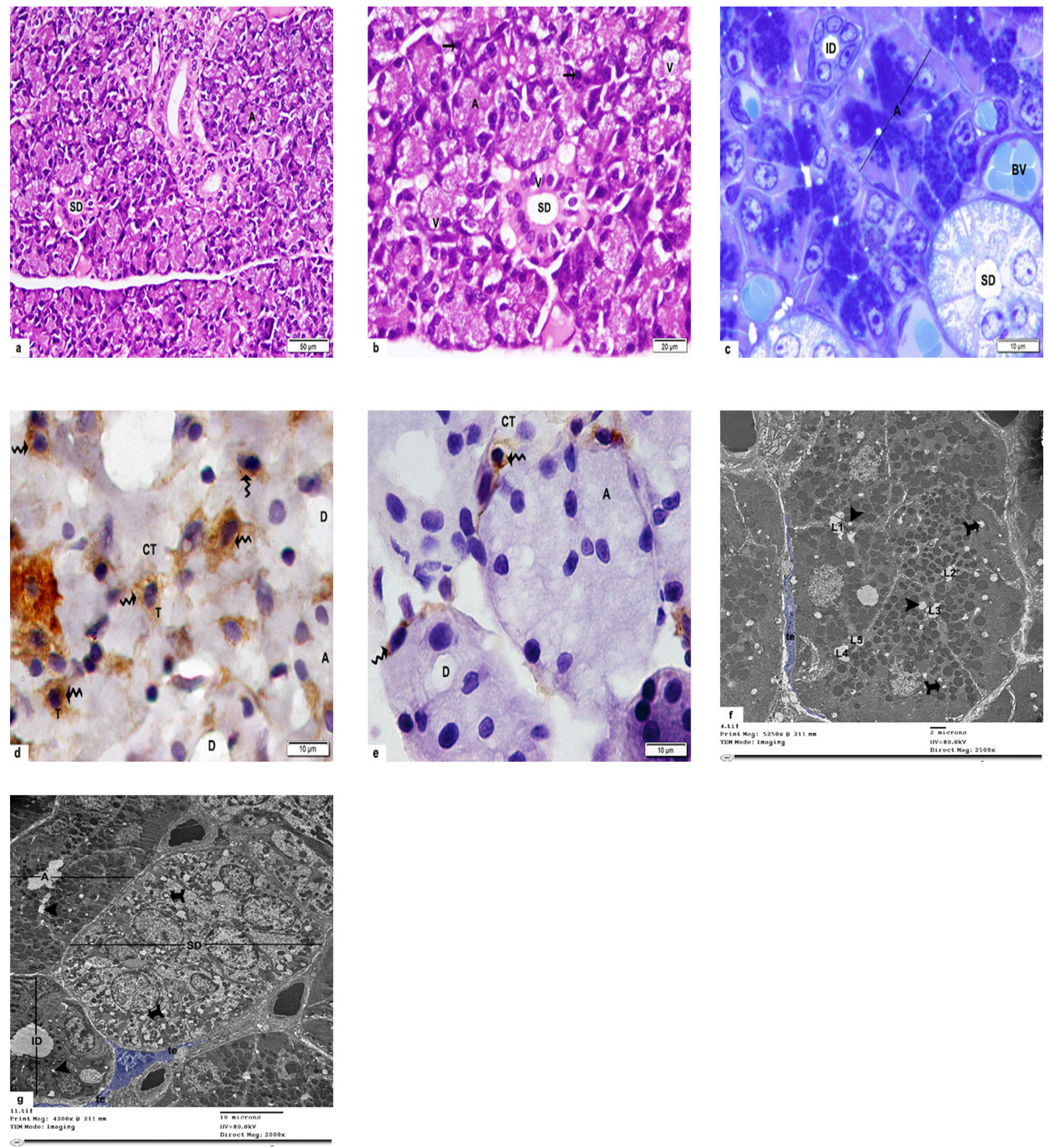

Fig. 3: Light microscopical photomicrographs of group III sections illustrating: a \& its higher magnification b: Apparently, normal histological picture of the acini (A) \& striated duct (SD), except for the presence of few vacuolations (V) and dark nuclei (thin arrows) [H\&E, x200 \& x400]. c Acini (A), intercalated duct (ID) and striated duct (SD) look apparently normal. Congested blood vessels (BV) can be seen [Toluidine blue, x1000]. d: Multiple CD34 immune-positive cells (stem cells and telocytes) (wavy arrows) are noted around the acini (A) \& ducts (D) within the CT septa (CT). Some of these cells have prolongations suggesting that they are telocytes (T) [anti CD34 immunohistochemical stain, x1000]. e: Observable increase in PDGFR- $\alpha$ immune-positive telocytes with their characteristic telopods (wavy arrows) around the acini (A) \& ducts (D) within the septa (CT) [anti PDGFR- $\alpha$ immunohistochemical stain, x1000].

TEM photomicrographs of group III sections showing: f: Multiple lumina (L1-5) of multiple nearly normal acini. However, degenerated mitochondria (bifid arrows) and vacuolations (arrowheads) can be noticed. Telopode (te) (digitally colored blue) is also seen [x2500]. g: Acini (A) and intercalated duct (ID) with few vacuolations (arrow heads) and triangular shaped telocyte with their telopodes (te) (digitally colored blue) are demonstrated. While degenerated mitochondria (bifid arrows) are obviously seen in striated duct (SD) [x2000]. 


\section{DISCUSSION}

Oral mucositis, a major chemotherapy side-effect, badly affects patient's nutrition and quality of life during and after treatment. It may be as severe as limiting the chemotherapeutic doses and increasing morbidities and mortalities ${ }^{[6,12]}$. Salivary dysfunction was reported secondary to chemotherapy and exaggerate chemotherapy-induced mucositis ${ }^{[12]}$.

In this study, MTX was used as a chemotherapy model widely used in several neoplasms treatment as acute leukaemias and lung and breast cancers ${ }^{[12]}$. It is also recommended for non-neoplastic diseases as psoriasis and autoimmune diseases as rheumatoid $\operatorname{arthritis}^{[30]}$

Additionally, the parotid gland, which is the largest major salivary gland that accounts for more than 50\% of stimulated saliva secretion ${ }^{[31]}$, was chosen. Besides, it is less affected by drugs as the time taken for the drug to reach its maximum concentration in parotid's saliva is longer than that in submandibular ${ }^{[32]}$.

MTX group revealed diarrhoea with a significantly decreased body weight. This weight loss is consistent with what stated to occur following other chemotherapies ${ }^{[3,5]}$ and could attributed to mucositis occurred 24-48 $\mathrm{h}$ after chemotherapy ${ }^{[6]}$ with its subsequent diarrhoea and decrease in food consumption $^{[33]}$.

In addition, there was glandular degeneration determined by marked vacuolations in almost all acinar and ductal cells and complete replacement of some acinar cells by large vacuoles. Such findings might be explained by the accumulation of lipid droplets which were stated by authors of previous studies ${ }^{[34}$, ${ }^{35}$ to be unutilized fatty acids resulted from cellular dysfunction. They added that, these fat droplets might coalesce together forming a large vacuole and consequently lipid degeneration and cellular death. Similarly and as a result of acinar basement membrane loss, this merge might occur between cells of adjacent acini leading to acinar amalgamation. A parallel finding was listed in rats' small intestine following $\mathrm{MTX}^{[36]}$.

Another explanation of such vacuolations might be mitochondrial swelling ${ }^{[37]}$ identified in both acini and ducts. Further clarification could come from altered secretory materials detailed in another study ${ }^{[32]}$ where there were electron-lucent granules and significantly decreased PAS density in acinar and ductal cells.

Additionally, there was acinar enlargement supported by significantly increased diameter in this group versus control group. Such enlargement was presumed to be due to accumulation of fat droplets and/or mitochondrial swelling. Another explanation for this enlargement was the glandular dysfunction and failure of secretion with subsequent accumulation of the secretory granules in the acinar cells ${ }^{[19]}$.

This MTX-induced acinar and ductal cell death was assumed to be due to apoptosis, which was supported in our study by the presence of shrunken dark irregular acinar and ductal nuclei in addition to, chromatin clumping in some acinar and ID nuclei. More reinforcement came from the demonstrated rER dilatation and mitochondrial swelling and degeneration which were considered as cellular changes preceding apoptosis ${ }^{[38]}$. This assumption was strengthened previously by denser Fas (apoptotic marker) immunoreaction in submandibular gland following MTX ${ }^{[35]}$ and increased number of apoptotic bodies following chemotherapy ${ }^{[3]}$.

Acinar and ductal cell deaths following MTX were proved to be replaced by $\mathrm{CT}^{[19,35]}$. This was supported in our results by glandular disorganization, widening of the fibrous septa with numerous adipocytes and increased collagen fibers in ultrathin sections.

All these previous findings might be elucidated by MTX-induced oxidative stress (OS). It was evidenced to reduce intracellular glutathione-based antioxidants and produce oxygen free radicals during its intracellular metabolism. This oxidant/antioxidant imbalance leads to lipid peroxidation followed by organelles and plasma membranes lysis ${ }^{[39,40]}$. Such lipid peroxidation was enforced by significantly increased MDA value, acinar and ductal cell membrane rupture and ductal epithelial discontinuity in MTX group.

This parotid damage could be enlightened by another mechanism where MTX binds to dihydrofolic reductase preventing the change of folic to folinic acid (its active form). This, in turn, hinders nucleic acids, amino acids and proteins synthesis with consequent membrane damage, cellular death and altered salivary secretion $^{[41]}$. Such mechanism was supported by the marked reduction obtained in acinar and ID secretory granules size and content, significant decrease in total protein, amylase activity and acini and ducts' numbers. These were followed by significant drop of the unstimulated parotid weight despite the detected acinar enlargement and ductal dilatation.

The demonstrated duct system dilatation was enforced by significantly increased diameter in group II. It was similarly reported in former studies ${ }^{[19,35]}$ attributed to MTX negative effect on myoepithelial cells embracing the ducts. This led to the stagnant secretion detected in this group and consequently salivary dysfunction, failure of saliva ejection into the mouth and xerostomia ${ }^{[42]}$. In addition, SDs could 
not be distinguished clearly. Most probably, this was due to the detected epithelial height reduction and loss of basal infoldings. These findings were reported formerly ${ }^{[19]}$ and could be explained by MTX-induced degeneration of these cells.

The determined marked dilatation and congestion of the blood vessels were equally reported following MTX and 5-flourouracil ${ }^{[19,43]}$. These inflammatory reactions could aim to transport more blood to the degenerated tissues ${ }^{[44]}$. Accordingly, inflammatory reactions "such as mononuclear infiltration and the presence of mast cells with dispersed granules within the thickened septa" could be explained.

Telocytes were deteriorated by MTX, as well. Their degenerative features are concomitant with those identified previously in cases of systemic sclerosis, cyclophosphamide-induced premature ovarian failure and psoriasis ${ }^{[45-47]}$. It was presumed to be due to MTXinduced blocking of protein synthesis and/or OS as telocytes were proved to be affected by $\mathrm{OS}^{[48]}$. This deterioration was supported by the significant decrease of PDGFR $-\alpha+$ cell in group II.

Unexpectedly, CD34+ cells showed significant increase in group II which could be clarified by that CD34 is a marker for both telocytes and BMHSCs. BMHSCs are able to home to the site of lesion by certain signals produced by the injured tissues ${ }^{[49]}$. Such homing was enforced by significant increase in BMHSCs number in MTX group. This significant increase in stem cell number did not only compensate the significant decrease in PDGFR- $\alpha+$ cell but also resulted in significant increase in CD34+ cells.

Telocytes affection in this group was supposed to exaggerate the acinar and ductal cells degeneration, where it was reported that telocytes were able to control the intercellular signalling. This control is mediated by their long prolongations 3D network that interacts with the other telocytes, different parenchymatous cells, nerve endings and blood vessels. Such interaction occur either directly through paracrine and/or juxtacrine signals or indirectly through microvesicles shedding which transfer proteins, RNA and microRNA ${ }^{[18]}$.

Moreover, telocytes are present in adult stem cell niches surrounding the stem cells with their telopodes, which allows telocytes to communicate with these stem cells either directly or indirectly and nurse them via controlling their extracellular milieu homeostasis and presenting physical and informational support ${ }^{[50]}$. This is mediated by their various intercellular signals and shed microvesicles ${ }^{[51]}$. Accordingly, telocytes are called stem cell helpers where they play an important role in stem cells tissue regenerative process $^{[52,53]}$.
Bearing in mind that this nursing effect could be lost with degeneration of telocytes, it could be assumed that the degenerated telocytes might exaggerate tissue stem cells injury proved to occur following chemotherapy ${ }^{[54]}$. This assumption is consistent with that suggested in cases of psoriasis ${ }^{[47]}$. Such adult stem cells injury was, subsequently, suggested to augment the parotid gland degeneration as it was documented that these stem cells within their niches coordinate the tissue renewal in different organs ${ }^{[55]}$

In this study, G-CSF was used to mobilize BMHSCs as reported before ${ }^{[15]}$. Maximum mobilization was specified to occur after 4-6 days ${ }^{[56]}$. Thus, this agent was used, in this work, for 5 days.

Group III rats showed improvement of their general conditions proved by the stoppage of diarrhoea and body weight significant increase versus group II and non-significant decrease than control group. Moreover, there was almost normal parotid gland histological architecture except for the presence of few pyknotic nuclei, vacuolations and congested blood vessels besides multiple adjacent lumina which indicated that some acini were still amalgamated. Furthermore, MDA level significant decrease versus group II and non-significant increase than group I were detected. This, in turn, could indicate decrease lipid peroxidation and cellular injury.

Such parotid preservation was reflected on its function where significant increase in unstimulated parotid weight, acini and ducts' number, total protein and amylase activity versus group II and their nonsignificant decrease than control group were found. Additionally, there were acinar and ductal diameters significant decrease than MTX group and nonsignificant increase versus group I. These findings are supported by the previously reported therapeutic effect of G-CSF on liver, kidney and brain lesions and irradiated salivary glands ${ }^{[15,57-59]}$. Such G-CSF preservative influence was explained by its BMHSCs mobilizing effect ${ }^{[60]}$ supported in this work by BMHSCs significant increase in Neupogen-treated group compared to MTX group.

Stem cells could support the injured tissues via anti-inflammatory, immunosuppressive, anti-apoptotic and antioxidant effects in addition to consumption of pro-apoptotic and inflammatory molecules ${ }^{[61]}$. They could also reinforce tissue stem cells to proliferate and replace the damaged cells ${ }^{[37]}$. These BMHSCs reparative effects might occur through paracrine secretion of trophic factors as cytokines, chemokines and growth factors ${ }^{[59]}$.

In group III, G-CSF was given 1 day after MTX administration, then these animals were sacrificed 6 
days after MTX. Based on that BMHSCs mobilization started after 3 days of G-CSF treatment and reached its maximum after 5 days $^{[15]}$ and MTX-induced salivary gland lesion occurred as early as 2 days ${ }^{[19]}$. It was proposed that BMHSCs mobilization was started to occur 4 days after MTX administration i.e. 2 days after induction of parotid lesion and reached its maximum after 6 days of MTX administration i.e. day of sacrifice. Therefore, the approximately perfect parotid histological preservation in group III was not only due to mobilized BMHSCs but also due to G-CSF itself. This suggestion was stated previously while treated renal ischemia by G-CSF${ }^{[57]}$. Furthermore, this is supported by the anti-apoptotic, anti-inflammatory, immunomodulatory and lipid peroxidation inhibiting effects of G-CSF ${ }^{[62-64]}$.

Telocytes preservation detected in this group was suggested to result from protective effects of G-CSF and/or mobilized BMHSCs. It was backed by PDGFR $-\alpha+$ cells significant increase than MTX group and non-significant decrease than control group. Such significant increase of PDGFR- $\alpha+$ cells and BMHSCs in group III versus group II could explain CD34+ cell significant increase in the same group compared to MTX group.

The preserved telocytes were supposed to support the parotid acini and duct system through controlling their extracellular milieu by their prolongations communicating network ${ }^{[18]}$. In addition, telocytes nursing effect on tissue stem cells could similarly occur with the mobilized BMHSCs. Accordingly, a communicating network formed between BMHSCs, nerve endings, blood vessels, acinar and ductal cells transmitting BMHSCs trophic factors to these cells. Thus, conservation of telocytes could be another way for G-CSF preservation effects.

\section{CONCLUSION}

MTX, a chemotherapy model, induced parotid gland degeneration through OS and/or decreased protein synthesis. G-CSF could treat this gland via BMHSCs mobilization in addition to its anti-apoptotic, antiinflammatory and lipid peroxidation inhibition effects as well as telocytes preservation.

\section{CONFLICT OF INTEREST}

No conflict of interest

\section{REFERENCES}

1. Klareskog L, van der Heijde D, de Jager JP, Gough A, Kalden J, Malaise M, Martín Mola E, Pavelka K, Sany J, Settas L, Wajdula J, Pedersen R, Fatenejad S, Sanda M. Therapeutic effect of the combination of etanerceept and methotrexate compared with each treatment alone in patients with rheumatoid arthritis:
Double blind randomized controlled trial. Lancet 2004; 363: 675-681.

2. Terzi S, Özgür A, Mercantepe T, Çeliker M, Tümkaya L, Dursun E. The effects of astaxanthin on salivary gland damage caused by cisplatin in the rat. Int J Res Med Sci 2017; 5:1410-1414.

3. Al-Moula AD, Al-Mashhadane F, Mammdoh JK. Effects of 6-mercaptopurine on salivary glands in rabbit. Al-Rafidain Dent J 2012; 12: 66-273.

4. Shea B, Swinden M, Tanjong Ghogomu E, Ortiz Z, Katchamart W, Rader T, Bombardier C, Wells GA, Tugwell P. Folic acid and folinic acid for reducing side effects in patients receiving methotrexate for rheumatoid arthritis. Cochrane Database Syst Rev 2013; 31: CD000951.

5. Ozel O, Aycicek A, Kenar F, Aktepe F, Sargin R, Yilmaz MD, Derekoy FS. Histopathologic changes in the rabbit submandibular gland after 5-fluorouracil chemotherapy. Turk J Med Sci 2010; 40: 213-220.

6. Ohrn KE, Sjödén PO, Wahlin YB, Elf M. Oral health and quality of life among patients with head and neck cancer or haematological malignancies. Support Care Cancer 2001; 9: 528-538.

7. Sonis ST Oral mucositis in cancer therapy. J Support Oncol 2004; 2: 3-8.

8. Mednieks MI, Szczepanski A, Clark B, Hand AR. Protein expression in salivary glands of rats with streptozotocin Diabetes. Int J Exp Path 2009; 90: 412-422.

9. Edgar M, Dawes C, O'Mullane D. The anatomy and physiology of salivary glands, In Saliva and Oral Health. 4 th eds., Stephen Nancocks Ltd 2012. pp. $1-16$.

10. Chamani G, Zarei MR, Mehrabani M, Taghiabadi Y. Evaluation of Effects of Zingiber officinale on Salivation in Rats. Acta Medica Iranica 2011; 49: 336 340 .

11. Mese H, Matsuo R. Salivary secretion, taste and hyposalivation. J Oral Rehabil 2007; 34:711-23.

12. Jensen SB, Pedersen AM, Reibel J, Nauntofte B. Xerostomia and hypofunction of salivary glands in cancer therapy. Support Care Cancer 2003; 11: 207225 .

13. Jellema AP, Slotman BJ, Doornaert P, Leemans CR, Langendijk JA. Impact of radiation-induced xerostomia on quality of life after primary radiotherapy 
among patients with head and neck cancer. Int J Radiat Oncol Biol.Phys 2007; 69: 751-760.

14. Lapidot T, Dar A, Kollet O. How do stem cells find their way home? Blood 2005; 106: 1901-10.

15. Zhang L, Kang W, Lei Y, Han Q, Zhang G, Lv Y, Li Z, Lou S, Liu Z. Granulocyte colony-stimulating factor treatment ameliorates liver injury and improves survival in rats with d-galactosamine-induced acute liver failure. Toxicolo Lett 2011; 204: 92-99.

16. Faussone-Pellegrini MS, Popescu LM. Telocytes. Biomol Concepts 2011; 2: 481- 489.

17. Popescu LM, Nicolescu MI. Telocytes and stem cells. In: Resident stem cells and regenerative therapy. Edited by: Regina Coeli dos Santos Goldenberg, Antonio Carlos Campos de Carvalho, Elsevier. 2013. pp: 205-231.

18. Popescu LM, Faussone-Pellegrini MS. Telocytes - a case of serendipity the winding way from interstitial cells of Cajal (ICC), via interstitial Cajal-like cells (ICLC) to telocytes. J Cell Mol Med 2010; 14: 729 740 .

19. Al-Refai AS, Khaleel AK, Ali S. The Effect of Green Tea Extract on Submandibular Salivary Gland of Methotrexate Treated Albino Rats: Immunohistochemical Study. J Cytol Histol 2014; 5, 6 pages.

20. El-Akabawy G, El-Kholy W. Neuroprotective effect of ginger in the brain of streprozotocin-induced diabetic rats. Ann Anat 2014; 169: 119- 128.

21. Oliveira TC, Bradaschia-Correa V, Castro JR, Simões A, Arana-Chavez VE. Ultrastructural and biochemical analysis of the effects of alendronate on salivary glands of young rats. Arch Oral Bio 2014; 59: 130 $7-1311$.

22. Lowry OH, Rosebrough $\neg$ NJ, Farr AL, Randall RJ. Protein measurement with the Folin phenol reagent. J Biol Chem 1951; 193: 265-275.

23. Caraway WT. A stable starch substrate for the determination of amylase in serum and other body fluids. Am J Cli Pathol 1959; 32: 97-99.

24. Wills ED. Evaluation of lipid peroxidation in lipids and biological membranes. In: Biochemical toxicology: A practical approach. 1st ed. London: Oxford; 1987. pp. $1-304$.

25. Kiernan J. Histological and histochemical methods: theory and practice. 3rd ed. Arnold publisher. London, New York \& New Delhi. 2001. pp. 111-162.
26. Bancroft J, Gamble M. Theory and Practice of Histological Techniques. Staining methods. 7th ed. Edinburgh, London, Madrid, Melbourne, New York and Tokyo: Churchill Livingstone; 2008. pp. 263-325.

27. Hayat MA. Chemical fixation. In: Principles and techniques of electron microscopy: biological applications. 4th ed. Edinburg, UK: Cambridge University Press. 2000. pp.4-85.

28. Dykstra MJ and Reuss LE. Staining methods for semithins and ultra thins. In: Biological electron microscopy, theory, techniques and troubleshooting. 2nd ed. Kluwer Academic Publishers/Plenum Publishers. 2003. pp.175- 196.

29. Emsley R, Dunn G, White IR. Mediation and moderation of treatment effects in randomised controlled trials of complex interventions. Stat Methods Med Res. 2010; 19: 237-270.

30. Antunes NL, Souweidane MM, Lis E, Rosenblum MK, Steinherz PG. Methotrexate leukoencephalopathy presenting as Kluver-Bucy syndrome and uncinate seizures. Pediatr Neurol 2002; 26: 305-308.

31. Humphrey SP, Williamson RT. A review of saliva: Normal composition, flow, and function. J Prosthet Dent 2001; 85:162-169.

32. Ibrahim SH, Soliman ME, Yehia M. Effect of ciprofloxacin on the submandibular salivary gland of adult male albino rat, a light and electron microscope study. The Egyptian Journal of Histology 2004; 27: 339-354.

33. Stringer AM, Gibson RJ, Logan RM, Bowen JM, Yeoh AS, Burns J, and Keefe DM. Chemotherapy induced diarrhea is associated with changes in the luminal environment in the DA rat. Exp Biol Med 2007; 232: 96-106.

34. Mahmoud EF, Mahmoud MF, Abd Al Haleem M. Royal Jelly ameliorates oxidative stress and tissue injury in submandibular salivary gland of methotrexate treated rabbits: Immunohistochemical study. J Am Sci 2012; 8: 501-508.

35. El-Agamy AA, Afifi OK, Sheta AA. Protective Role of Panax Gensing on Fluvoxamine Maleate Induced Structural Changes in the Submandibular Salivary Gland of Rats. Nat Sci 2014; 12: 21-29.

36. Kolli VK, Abraham P, Rabi S. Methotrexate induced nitrosative stress may play a critical role in small intestinal damage in the rat. Arch Toxicol 2008; 82: 763-770. 
37. Lombaert IM, Brunsting JF, Wierenga PK, Kampinga HH, de Haan G, Coppes RP. Cytokine treatment improves parenchymal and vascular damage of salivary glands after irradiation. Clin Cancer Res 2008 ; $14: 7741-7750$.

38. Takahashi S, Nakamura S, Domon $\mathrm{T}$, Yamamoto T, Wakita M. Active participation of apoptosis and mitosis in sublingual gland regeneration of the rat following release from duct ligation. J Mol Histol 2005; 36: 199-205.

39. Solary E, Droin N, Bettaieb A, Corcosl D, Biotrel MT, Garriodo C. Positive and negative regulation of apoptotic pathways by cytotoxic agents in hematological malignancies. Leukemia 2000; 14: 1833-1849.

40. Hsu PC, Hour TC, Liao YF, Hun YC, Chang WH, Kao MC, Tsay GJ, Hung HC, Liu GY. Increasing ornithine decarboxylase activity is another way of prolactin preventing methotrexate-induced apoptosis: Crosstalk between ODC and BCL -2. Apoptosis 2006; 11: 38999.

41. Mardini H, Record C. Detection assessment and monitoring of hepatic fibrosis: biochemistry or biopsy? Ann Clin Biochem 2005; 42: 441-7.

42. Moheb M, El-Sakhawy M A, Sherif H, Shredah M. Histological evaluation of the effect of nutmeg on parotid salivary glands of adult male albino rats. Life Sci J 2014; 11: 1063-1068.

43. Zahawi SM. Impact of Chamomile on Submandibular Salivary Gland of 5-Fluorouracil Treated Rabbits (Histological and Immunohistochemical Study). J Clin Cell Immunol 2015; 6: 366.

44. Moubarak R. The effect of hypercholesterolemia on the rat parotid salivary gland (histopathological and immunohistochemical study). Cairo Dental Journal 2008; 24:19-28.

45. Manetti M, Guiducci S, Ruffo M, Rosa I, FaussonePellegrini MS, Matucci-Cerinic M, Ibba-Manneschi L. Evidence for progressive reduction and loss of telocytes in the dermal cellular network of systemic sclerosis. J Cell Mol Med 2013; 17: 482-496.

46. Manole CG, Gherghiceanu M, Simionescu O. Telocyte dynamics in psoriasis. J Cell Mol Med 2015; 19: 1504-1519.

47. Liu T, Wang S, Li Q, Huang Y, Chen C, Zheng J. Telocytes as potential targets in a cyclophosphamide induced animal model of premature ovarian failure. Mol Med Rep 2016; 14: 2415-22.
48. Jensen GS, Drapeau C. The use of in situ bone marrow stem cells for the treatment of various degenerative diseases. Med Hypotheses 2002; 59: 422-428.

49. Enciu, AM, Popescu LM. Telopodes of telocytes are influenced in vitro by redox conditions and ageing. Mol Cell Biochem 2015; 410: 165-74.

50. Xiangdong W, Dragos C. Telocytes. Connecting cells. Advances in experimental medicine and biology. Springer. 2016. pp. 1- 440.

51. 51- El Maadawi ZM. Telocyte: a newly described interstitial cell. The Egyptian Journal of Histology 2012, 35:366-370.

52. 52- Popescu LM, Curici A, Wang E, Zhang H, Hu S, Gherghiceanu M. )Telocytes and putative stem cells in ageing human heart. J Cell Mol Med 2014; 19: 3145.

53. Wang F, Song Y, Bei Y, Zhao Y, Xiao J, Yang C. Telocytes in liver regeneration: Possible roles. J Cell Mol Med 2014; 18: 17201726.

54. Sonis ST. Pathobiology of mucositis. Semin Oncol Nurs 2004; 20: 11-15.

55. Walker MR, Patel KK, Stappenbeck TS. The stem cell niche. J Pathol 2009; 217:169-180.

56. Stroncek DF, Clay ME, Petzoldt ML, Smith J, Jaszcz W, Oldham FB, McCullough J. Treatment of normal individuals with granulocyte-colony stimulating factor: donor experiences and the effects on peripheral blood CD34+ cell counts and on the collection of peripheral blood stem cells. Transfusion 1996; 36: 601-610.

57. Stokman G, Leemans JC, Claessen N, Weening JJ, Florquin S. Hematopoietic stem cell mobilization therapy accelerates recovery of renal function independent of stem cell contribution. J Am Soc Nephrol 2005; 16: 1684-1692.

58. England TJ, Gibson CL, Bath, PM. Granulocytecolony stimulating factor in experimental stroke and its effects on infarct size and functional outcome: asystematic review. Brain Res Rev 2009; 62: 71-82.

59. Lombaert IM, Wierenga PK, Kok T, Kampinga HH, deHaan G, Coppes RP. Mobilization of bone marrow stem cells by granulocyte colony-stimulating factor ameliorates radiation-induced damage to salivary glands. Clin Cancer Res 2006; 12: 1804-1812.

60. Piscaglia AC, Shupe TD, Oh SH, Gasbarrini A, Petersen BE. Granulocyte colony stimulating factor promotes liver repair and induces oval cell migration 
and proliferation in rats. Gastroenterology 2007; 133 : 619-631.

61. Baraniak PR, McDevitt TC. Stem cell paracrine actions and tissue regeneration Regen Med 2010; 5: 121-143.

62. Kang W, Liu ZW, Han QY, Zhang L, Lei Y, Lou S. Effects of granulocyte colony-stimulating factor on hepatocyte apoptosis in acute liver failure: experiment with rats. Zhonghua Yi Xue Za Zhi (Chin Med J) 2008; 88: 980-984.
63. Hou XW, Jiang Y, Wang LF, Xu HY, Lin HM, He $\mathrm{XY}$, He JJ, Zhang S. Protective role of granulocyte colony-stimulating factor against adriamycin induced cardiac, renal and hepatic toxicities. Toxicol Lett $2009 ; 187: 40-44$.

64. Liu Q. Role of cytokines in the pathophysiology of acute-on-chronic liver failure. Blood Purif 2009; 28: 331-341. 
الملخص العربى

الآليات العلاجية للعامل المحفز لمستعمرات الخلايا المحبية في إصابة الغدة النكفية في الجرذان البالغة المحدثة بالميثوتريكسيث والدور المحتمل للخلايا ذات الإمتدادات: دراسة هستولوجية إبه

\section{عبيز إبراهيم عمر، مروة محمد بسري ، إيمان عباس فرج قسم علم الأنسجة ـ كلية الطب ـ جامعة القاهرة}

الخلفية: يستخدم ميثوتريكسيت (MTX) في جميع أنحاء العالم لعلاج الأورام و غير ها من الأمر اض غير السرطانية بالر غم من آثاره الجانبية الثنديدة. يعتبر الاختلال اللعابي أحد هذه الآثار الجانبية والذي يؤدي بدوره إلى تفاقم آثار ميثوتريكسيت السامة علي الأغشية المخاطية. و التى تعيق جودة حياة المرضى وتزيد من الأمر اض و الوفيات. ومن المعروف أن للعلاجات المتاحة للاختلال اللعابي العديد من السلبيات. وقد أظهر استخدام العامل المحفز لمستعمر ات الخلايا المحببة (G-CSF) لتحريك خلايا الدم الجذعية للنخاع العظمي نتائج و اعدة في العديد من الأمر اض. الهذف من الاراسة: اكتثاف التأثير العلاجي للعامل المحفز لمستعمرات الخلايا المحببة على إصابة الغدة النكفية المحدثة بالميثوتريكسيت و إلقاء الضوء على آلياتها المحتملة ودور الخلايا ذات الإمتدادات. المواد و طرق البحث: تم تقسيم واحد وأربعون من الجرذان البيضاء إلى ب مجموعات: الضابطة، الميثوتريكسيت و المعالجة بنيوبوجين. تم وزن جميع الحيو انات وتم التضحية بها بعد 1 أيام. وقد تم استخدام متجانس الغدة النكفية لستة جرذان من كل مجموعة لقياس تركيز البروتين الكلي، نشاط الأميليز وقيمة مالونديالدهيد (MDA). تمت معالجة الغدد النكفية اليمني من الحيو انات المتبقية من كل مجمو عة لإعداد بلوكات البار افين في حين تم معالجة الغدد النكفية اليسري لإعداد بلوكات الراتين. فحصت مقاطع البار افين المصبوغة بالهيماتوكسيلين والإيوسين والصبغة الهستوكيميائية المناعية ضد CD34 و عامل نمو المستقبلات ألفا الشتنق من الصفائح (PDGFRالجسم، و النتائج البيوكيميائية، و عدد الخلايا الإيجابية المناعية، و الفرق بين أعداد خلايا +CD34 و م- CDGFR + (عدد الخلايا الجذعية)، و عدد و أقطار الحويصلات والقنوات. النتائج: اظهرت مجموعة MTX اسهال، و انخفاض وزن الجسم، بالإضافة إلى تحلل خلايا الحويصلات و القنوات و الخلايا ذات الإمتدادات، بينما أوضحت المجمو عة المعالجة بنيوبوجين سمات نسيجية طبيعية تقريبا. وقد أظهرت المجمو عة المعالجة زيادة هستوكيميائية مناعية كبيرة في خلايا +CD34 و PDGFR- 2 وفي عدد الخلايا الجذعية مقابل مجمو عة MTX. الخلاصة: كان للعامل المحفز لمستعمرات الخلابا المحببة تأثير علاجي على تحلل الغدة النكفية المحدث بالميثوتريكسيت من خلال آثاره المباشرة، وتحريك خلايا الدم الجذعية للنخاع العظمي، و المحافظة على الخلايا ذات الامتدادات. 